\title{
Responses of reference evapotranspiration to changes in atmospheric humidity and air temperature in Spain
}

\author{
R. Moratiel ${ }^{1,2, *}$, J. M. Durán ${ }^{1,2}$, R. L. Snyder ${ }^{3}$ \\ ${ }^{1}$ Universidad Politécnica de Madrid, Departamento de Producción Vegetal: Fitotecnia, 28040 Madrid, Spain \\ ${ }^{2}$ CEIGRAM, Research Centre for the Management of Agricultural and Environmental Risks, 28040 Madrid, Spain \\ ${ }^{3}$ University of California, Davis, Department of Land, Air and Water Resources, Davis, California 95616, USA
}

\begin{abstract}
We studied the sensitivity of reference evapotranspiration $\left(E T_{\mathrm{o}}\right)$ to global warming in Spain at the end of the 21st century. The FAO-56 Penman-Monteith equation was used to estimate $E T_{0}$, and we examined the sensitivity of the latter to changes in temperature and relative humidity. Changes in stomatal resistance in response to increased $\mathrm{CO}_{2}$ concentration were not evaluated, nor were the changes in wind velocity and solar radiation. Different scenarios were used for estimation of future $E T_{\mathrm{o}}$ in different river basins as a consequence of trends in the maximum and minimum temperatures and maximum and minimum humidities during the period 1973-2002, as observed from 38 meteorological stations. The temperature increases ranged between 0.3 and $0.7^{\circ} \mathrm{C} \mathrm{decade}^{-1}$, and the relative humidities fluctuated between 0.1 and $-3.7 \%$ decade $^{-1}$. Four scenarios were simulated that considered the variations in linear tendency of the maximum and minimum temperatures and maximum and minimum relative humidities. The trends of the 4 scenarios were incorporated with the data from 338 agrometeorological stations to estimate future $E T_{0}$. In all cases, there was an annual increase in $E T_{\mathrm{o}}$ of $11,21,36$ and $7 \%$ above the annual $E T_{\mathrm{o}}(1196 \mathrm{~mm})$ for Scenarios $0,1,2$ and 3, respectively. The river basin most affected by these changes was the Ebro River valley. The most affected months were May, June, July and August, while the least affected months were November, December and January.
\end{abstract}

KEY WORDS: Evapotranspiration $\cdot$ Climate change $\cdot$ Temperature $\cdot$ Relative humidity $\cdot$ Spain

\section{INTRODUCTION}

Global warming due to the enhanced greenhouse effect is expected to cause major changes in various climatic variables, such as precipitation, absolute humidity, net terrestrial, solar radiation and temperature (IPCC 2007). Atmospheric temperature is the most widely used indicator of climatic changes both on global and regional scales, and global land-surface air temperatures have increased in the Northern Hemisphere by $0.3^{\circ} \mathrm{C}$ decade $^{-1}$ from 1979 to 2005 (Hansen et al. 2001, Smith \& Reynolds 2005, Brohan et al. 2006, Lugina et al. 2007). According to Brunet et al. (2007), the annual daily mean temperature in
Spain, estimated by linear trend, has increased by $0.48^{\circ} \mathrm{C}$ decade $^{-1}$ from 1973 to 2005

The combination of 2 separate processes, where water is lost from the soil surface by evaporation and from the crop by transpiration, is referred to as evapotranspiration. Hydrological parameters such as precipitation, evapotranspiration, ground water and soil moisture are likely to change with climate (Gleick 1986), and the impact of climate change on evapotranspiration rates is important for hydrologic processes and, hence, water resources planning. Crop water requirements depend upon several climatic parameters, including rainfall, radiation, temperature, humidity and wind speed. Therefore, any change in climatic 
parameters due to global warming will also affect evapotranspiration (Goyal 2004). Global warming in arid and semiarid regions is expected to increase dry conditions over southeastern Spain, which is already characterized by a 5 to 7 mo dry season. Decreases in rainfall have been observed over the Iberian Peninsula since the early 1960s (Palutikof 2003), but increases have been noted in the northern coastal regions of Spain (Esteban-Parra et al. 2003). Esteban Parra et al. (2003) have reported significant increases in mean annual and seasonal temperatures during the 20th century. Changes in climate along the Mediterranean coast have received particular attention in the literature owing to their potential impact on water resources in the region (De Luís et al. 2000, Ramos \& Martínez-Casasnovas 2006, Bürger et al. 2007, Martínez et al. 2007).

Globally, data consisting of direct measurements of actual evapotranspiration are limited. An indirect way to obtain estimates of evapotranspiration is the evaporation rate from pans filled with water, known as pan evaporation $\left(E_{\mathrm{pan}}\right)$. Trends in $E_{\mathrm{pan}}$ have been reported with different conclusions depending on the region studied. In Israel, Cohen et al. (2002) showed ascending tendencies in $E_{\text {pan }}$ in the central coastal plain, and Da Silva (2004) also found ascending trends in the northeast of Brazil. However, Roderick \& Farquhar (2004) in Australia, Tebakari et al. (2005) in Thailand, Qian et al. (2006) and Xu et al. (2006) in China and Burn \& Hesch (2007) in Canada all reported decreasing trends in $E_{\text {pan. }}$. Jhajharia et al. (2009) found both decreasing and increasing tendencies in $E_{\text {pan }}$ in northeast India, depending on the location of the station. Decreases in $E_{\text {pan }}$ have been attributed to decreasing surface solar radiation and wind speed (Xu et al. 2006), and increases in cloud cover, greater air pollution and higher concentrations of atmospheric aerosols (Liepert 2002, Liepert et al. 2004). Roderick \& Farquhar (2002) observed a decrease in $E_{\text {pan }}$, and they related this to the decreases in solar irradiance and the associated changes in diurnal temperature range and vapour pressure deficit observed by other authors. In various European regions, the decreasing water requirement of the crops can be attributed to a shorter growing season as a result of increasing temperatures in spring, a reduction of the evaporative demand as a result of the diminishing global radiation, or a combination of these two (Supit et al. 2010). Pan evaporation depends on the water surface temperature and energy balance between the evaporation pan, water and the atmosphere. If the humidity does not change, increasing water temperature should increase evaporation. If the humidity increases, it will partially offset the impact of higher temperature on the evaporation. Evapotranspiration also depends on these factors, but it also depends on biological factors such as plant growth, canopy structure and stomatal responses to the environment.

Small changes in evapotranspiration can have important consequences in arid climates. For example, Goyal (2004) reported that a 1\% temperature increase could increase evapotranspiration by $12.69 \%$ in arid regions of Rajasthan, India, where the annual rainfall varies from 100 to $400 \mathrm{~mm}$ and mean temperature varies by about $25^{\circ} \mathrm{C}$. According to Anderson et al. (2008), an evapotranspiration increase of $18.7 \%$ resulted from a $3^{\circ} \mathrm{C}$ rise in air temperature in California with an annual average precipitation of $640 \mathrm{~mm}$ and mean temperature about $15^{\circ} \mathrm{C}$. At the end of the $1980 \mathrm{~s}$, Martin et al. (1989) and Rosenberg et al. (1989) reported an increase in evapotranspiration over grassland of $17 \%$ with an air temperature increase of $3^{\circ} \mathrm{C}$ based on measurements taken during summer in northeastern Kansas with temperatures ranging between 24 and $35^{\circ} \mathrm{C}$.

Under the A1B scenario, the annual mean warming from 1980-1999 to 2080-2099 will vary from 2.2 to $5.1^{\circ} \mathrm{C}$ in southern Europe and the Mediterranean region (Christensen et al. 2007). According to Räisänen et al. (2004), future warming will be largest during northern European winters and southern European summers. Increased precipitation is expected in northern European winters, and decreased precipitation is anticipated in southern European summers.

An increase in $\mathrm{CO}_{2}$ can lead to the closing of plant stomata, thereby increasing the resistance of the vapour flow through the transpiring plant and evaporating soil surface (canopy or surface resistance, respectively) and reduced evapotranspiration rates (Long et al. 2004). Higher temperatures can increase growth rates and shorten growing seasons of annual crops. In some cases, this can impact the seasonal evapotranspiration, e.g. a $4 \%$ decrease in seasonal total evapotranspiration for rice was observed for each $1^{\circ} \mathrm{C}$ increase in air temperature owing to a shorter growing season (Mahmood 1997). One common feature of regional climate change scenarios is their anticipation of drier summers over continental Europe (Giorgi et al. 2001, Rowell \& Jones 2006). Along with the resulting higher surface heating, drier weather could lead to more water stress and higher demand for water resources (Fink et al. 2004).

The objective of the present study was to estimate changes in reference evapotranspiration $\left(E T_{0}\right)$ by the end of the 21st century in Spain as a consequence of climate change using the standardized PenmanMonteith $E T_{\mathrm{o}}$ equation (Allen et al. 1998, 2006). Possible changes in temperature and humidity were evaluated; changes in wind speed, radiation and canopy resistance were not considered. 


\section{DATA AND METHODS}

\subsection{Study area and climate}

The Iberian Peninsula is located between the meridians $9^{\circ} \mathrm{W}$ and $3^{\circ} \mathrm{E}$, and the parallels $36^{\circ} \mathrm{N}$ and $43^{\circ} 50^{\prime}$ N. Spain has a mostly Mediterranean climate, which is characterized by a dry and hot summer and high rainfall and mild temperatures in the winter. Seasons vary greatly across the country. The southeast is characterized by a 5 to 7 mo dry season and the northwest and north have dry seasons of $<3$ mo (Rana \& Katerji 2000). Without irrigation, the water balance is extremely unfavorable for spring and summer crops in the southeast.

\subsection{Climate data}

Climatological data used in the present study can be divided in 2 groups: those used to identify the scenarios and those used to simulate the scenarios. In the former, 38 stations with complete data sets for the period 1973 to 2002 were used. For these stations, the maximum and minimum temperatures and maximum and minimum humidities, as well as trends in temperature and humidity, were analyzed for each river basin (Fig. 1, Table 1). Simulations were not performed for those stations where the scenarios were obtained, because the number of these was very small, and, at the majority of stations, the necessary sensors for the calculations of daily $E T_{\mathrm{o}}$ were not available. Simulations were applied to daily data from 338 stations of agro-meteorological networks (Sistema de información para el Regadío [SIAR]). These stations cover most
Table 1. Number of stations per river basin. Calculation: stations used to calculate scenarios; Simulation: stations used to simulate scenarios

\begin{tabular}{|llcc|}
\hline \multirow{2}{*}{ Zone } & \multirow{2}{*}{ Basin } & \multicolumn{2}{c|}{ Station } \\
\cline { 3 - 4 } & & Calculation & Simulation \\
\hline 1 & North & 5 & 5 \\
2 & Duero & 6 & 38 \\
3 & Tajo & 2 & 33 \\
4 & Guadiana & 2 & 32 \\
5 & Guadalquivir & 4 & 55 \\
6 & South & 2 & 18 \\
7 & Segura & 3 & 23 \\
8 & Júcar & 4 & 55 \\
9 & Ebro & 6 & 68 \\
10 & Inner Catalonia & 2 & 0 \\
11 & Balearic Island & 3 & 11 \\
& Total & 38 & 338 \\
\hline
\end{tabular}

of Spain (Fig. 1, Table 1). Data from each station included measurements of solar global radiation (pyranometer, SKYE SP1110); air temperature $\left(T_{\mathrm{a}}\right)$ and relative humidity $(R H$; HMP45C, Vaisala); wind speed $(u)$ and wind direction (anemometer and wind vane, RM Young 05103); and precipitation (ARG100 rain gauge). Sensors were periodically maintained and calibrated, and all data were recorded and averaged hourly on a data logger (CR10X, Campbell). Both hourly and daily climate data were archived by SIAR. The agrometeorological network SIAR was created in 1998, and has been widened in subsequent years, and has existed in its current form since 2001 (MARM 2010). Considering the years after 2001, we deduced that 2007 was the year with the least deviation in temperature relative to the reference period 1971-2000; mean temperature in

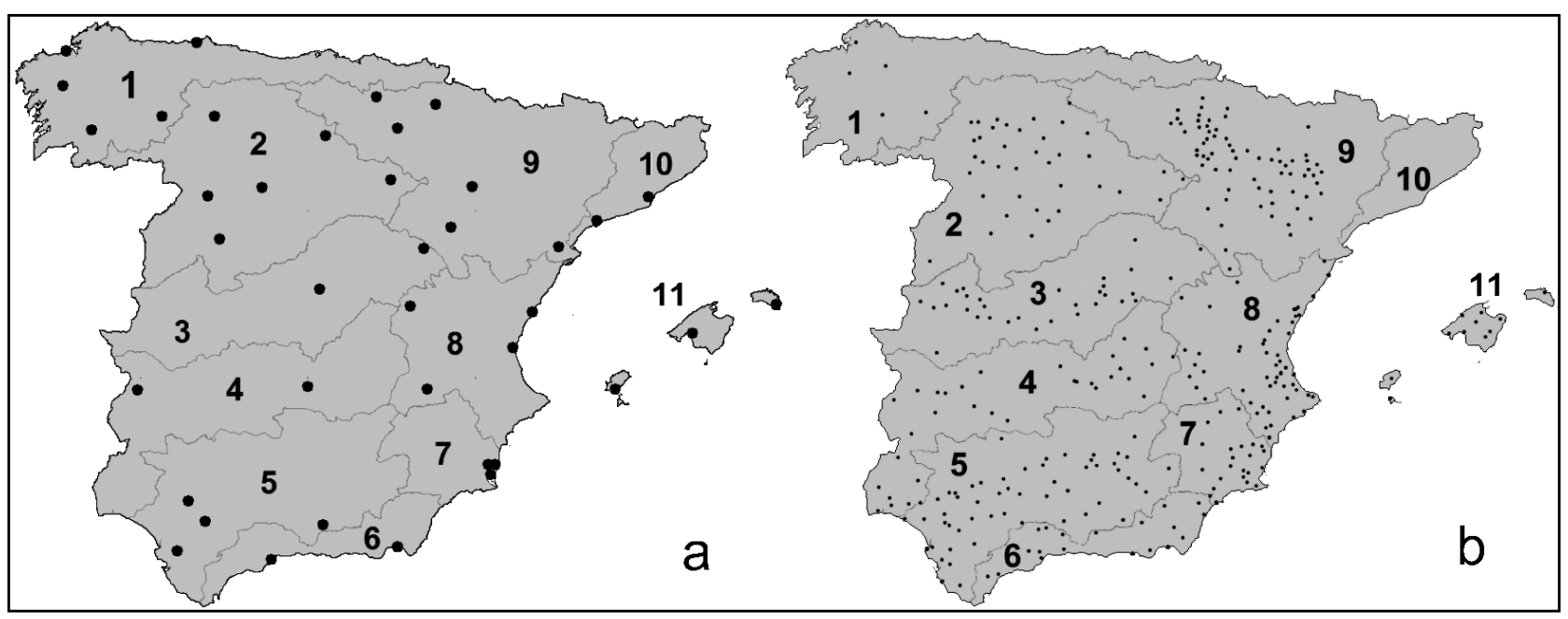

Fig. 1. Locations of the meteorological stations selected in Spain by river basin. 1: North; 2: Duero; 3: Tajo; 4: Guadiana; 5: Guadalquivir; 6: South; 7: Segura; 8: Júcar; 9: Ebro; 10: Inner Catalonia; 11: Balearic Island. (a) Stations used to calculate scenarios; (b) stations used to simulate scenarios 
2007 was just $0.4^{\circ} \mathrm{C}$ higher than that of the reference periods $\left(14.6^{\circ} \mathrm{C}\right)$, situating the mean temperature for 2007 at $15.0^{\circ} \mathrm{C}$. Temperature deviations in winter and spring were positive, while in summer and autumn they were insignificant (AEMET 2010). Therefore, the daily data for calculating $E T_{\mathrm{o}}$ were downloaded from the network websites for the year 2007.

\subsection{Calculations}

To create the different scenarios, we calculated the linear annual trends in maximum temperature, minimum temperature, maximum relative humidity and minimum relative humidity for each of the river basins during the period 1973-2002. Following this, we calculated the standard deviations for the $95 \%$ confidence interval (CI) trends and posed the following 4 scenarios: Scenario 0, increases in the average trends of maximum and minimum temperatures for each river basin; Scenario 1, increases in the average trends of maximum and minimum temperatures and humidities for each river basin; Scenario 2, increases in the maximum trends (within the $95 \% \mathrm{CI}$ ) for the maximum and minimum temperatures and maximum and minimum humidities for each river basin; and Scenario 3, increases in the minimum trends (within the 95\% CI) for the maximum and minimum temperatures and maximum and minimum humidities for each river basin.

Daily data for 2007 were used to calculate $E T_{0}$, which was estimated using the Penman-Monteith equation (Allen et al. 1998, 2006):

$$
E T_{\mathrm{o}}=\frac{0.408 \Delta\left(R_{\mathrm{n}}-G\right)+\gamma \frac{900}{T+273} u_{2}\left(e_{\mathrm{s}}-e_{\mathrm{a}}\right)}{\Delta+\gamma\left(1+0.34 u_{2}\right)}
$$

where $E T_{\mathrm{o}}$ is reference evapotranspiration $\left(\mathrm{mm} \mathrm{d}^{-1}\right), R_{\mathrm{n}}$ is net radiation at the surface $\left(\mathrm{MJ} \mathrm{m}^{-2} \mathrm{~d}^{-1}\right), G$ is ground heat flux density $\left(\mathrm{MJ} \mathrm{m}^{-2} \mathrm{~d}^{-1}\right), T$ is mean daily air temperature at $2 \mathrm{~m}$ height $\left({ }^{\circ} \mathrm{C}\right), u_{2}$ is wind speed at $2 \mathrm{~m}$ height $\left(\mathrm{m} \mathrm{s}^{-1}\right), e_{\mathrm{s}}$ is the saturation vapour pressure $(\mathrm{kPa}), e_{\mathrm{a}}$ is the actual vapour pressure $(\mathrm{kPa}), \Delta$ is the slope of the saturation vapour pressure curve $\left(\mathrm{kPa}{ }^{\circ} \mathrm{C}^{-1}\right)$ and $\gamma$ is a psychrometric constant $\left(\mathrm{kPa}^{\circ} \mathrm{C}^{-1}\right)$. Eq. (1) applies specifically to a hypothetical crop with an assumed height of $0.12 \mathrm{~m}$, a surface resistance of $70 \mathrm{~s} \mathrm{~m}^{-1}$ and an albedo of 0.23 .

Saturation vapour pressure at air temperature $T$, $e^{\circ}(T)$, was calculated using the following equation:

$$
e^{\circ}(T)=0.6108 \exp \left(\frac{17.27 T}{T+237.3}\right)
$$

Saturation vapour pressure for a day was estimated using the equation:

$$
e_{\mathrm{s}}=\frac{e^{\circ}\left(T_{\max }\right)+e^{\circ}\left(T_{\min }\right)}{2}
$$

where $T_{\max }$ and $T_{\min }$ are the daily maximum and minimum air temperatures $\left({ }^{\circ} \mathrm{C}\right)$, respectively.

Actual vapour pressure was estimated using the following equation:

$$
e_{\mathrm{a}}=\frac{e^{\circ}\left(T_{\max }\right) \frac{H R_{\max }}{100}+e^{\circ}\left(T_{\min }\right) \frac{H R_{\min }}{100}}{2}
$$

where $H R_{\max }$ and $H R_{\min }$ are the daily maximum and minimum relative humidities (\%), respectively.

A simple Excel application called Estimation de la Evapotranspiracion en España (EEEs) was developed to estimate the $E T_{\mathrm{o}}$ in Spain under different future situations. Using the daily data from 338 stations and Eq. (1), $E T_{\text {o }}$ was estimated for 2007 and for the 4 different scenarios. Maps of these data were generated using the Surfer ${ }^{\circledR} 8$ program.

\section{RESULTS}

\subsection{Calculating the scenarios}

Linear trends in changes in maximum and minimum temperature, and maximum and minimum relative humidity for the period 1973-2002 are presented in Table 2 . In all river basins, average increases in maximum temperature ranged from $+0.32^{\circ} \mathrm{C}$ decade $^{-1}$ (Segura) to $+0.71^{\circ} \mathrm{C}$ decade $^{-1}$ (Ebro). Average increases in minimum temperature ranged from $+0.28^{\circ} \mathrm{C}$ decade $^{-1}$ (Ebro) to $+0.72^{\circ} \mathrm{C}$ decade $^{-1}$ (Segura). For maximum relative humidity, all the average increments were negative, with the greatest decreases in the Inner Catalonia river basin $\left(-3.6 \%\right.$ decade $\left.^{-1}\right)$, compared with decreases of $-0.1 \%$ decade $^{-1}$ in the North river basin. Minimum relative humidity decreased for all river basins except Segura, which had positive increments of $+0.3 \%$ decade $^{-1}$. The strongest decrease in minimum relative humidity was found in the Ebro river basin, with a decrease of $-3.7 \%$ decade $^{-1}$.

Table 3 shows the scenarios given for the estimation of evapotranspiration at the end of the 21st century in accordance with Table 2 . In these 4 scenarios, we consider the most and least unfavorable situations for each of the river basins, as well as intermediate situations. Scenario 0 is the consequence of an increase in average temperature, without taking into account the variations in relative air humidity. Scenario 1 is the most probable, as we consider the average values of the tendencies for the 4 chosen variables. Scenario 2 takes the greatest extremes of the CI of the slope estimator with CI of $95 \%$, i.e. the increments of the highest temperatures and most negative relative humidity values. In 
Table 2. Annual temperature change estimated by a linear trend (parentheses: associated $95 \%$ confidence intervals) for maximum and minimum temperatures and maximum and mimimum relative humidity calculated over the period 1973-2002

\begin{tabular}{|lccccc|}
\hline River basin & $\begin{array}{c}\text { No. } \\
\text { stations }\end{array}$ & $\begin{array}{c}\text { Temperature maximum } \\
\left({ }^{\circ} \mathrm{C} \text { decade }{ }^{-1}\right)\end{array}$ & $\begin{array}{c}\text { Temperature minimum } \\
\left({ }^{\circ} \mathrm{C} \text { decade }^{-1}\right)\end{array}$ & $\begin{array}{c}\text { Maximum relative } \\
\text { humidity }\left(\% \text { decade }^{-1}\right)\end{array}$ & $\begin{array}{c}\text { Minimum relative } \\
\text { humidity }\left(\% \text { decade }^{-1}\right)\end{array}$ \\
\hline North & 5 & $0.44(0.64,0.23)$ & $0.36(0.52,0.20)$ & $-0.1(-0.5,0.3)$ & $-0.9(-1.5,-0.3)$ \\
Duero & 6 & $0.52(0.78,0.26)$ & $0.48(0.70,0.26)$ & $-0.5(-1.2,0.1)$ & $-1.6(-2.4,-0.8)$ \\
Tajo & 2 & $0.50(0.77,0.22)$ & $0.39(0.62,0.16)$ & $-1.0(-1.8,-0.2)$ & $-0.3(-1.2,0.6)$ \\
Guadiana & 2 & $0.51(0.80,0.24)$ & $0.97(1.24,0.70)$ & $-1.5(-2.4,-0.7)$ & $-2.2(-3.2,-1.2)$ \\
Guadalquivir & 4 & $0.49(0.74,0.24)$ & $0.55(0.79,0.30)$ & $-1.0(-1.7,-0.3)$ & $-1.1(-2.2,0.0)$ \\
South & 2 & $0.34(0.54,0.15)$ & $0.59(0.77,0.42)$ & $-2.5(-3.5,-1.5)$ & $-0.7(-1.7,0.3)$ \\
Segura & 3 & $0.32(0.50,0.14)$ & $0.72(0.92,0.52)$ & $-1.0(-1.9,-0.1)$ & $0.3(-0.6,1.3)$ \\
Júcar & 4 & $0.53(0.75,0.31)$ & $0.61(0.81,0.41)$ & $-1.4(-2.3,-0.4)$ & $-1.2(-2.4,0.0)$ \\
Ebro & 6 & $0.71(0.98,0.43)$ & $0.28(0.48,0.09)$ & $-0.5(-1.2,0.26)$ & $-1.2(-2.3,0.1)$ \\
Inner Catalonia & 2 & $0.59(0.78,0.40)$ & $0.57(0.76,0.38)$ & $-2.6(-3.5,-1.7)$ & $-3.7(-4.7,-2.7)$ \\
Balearic Island & 3 & $0.55(0.75,0.35)$ & $0.70(0.90,0.50)$ & $-1.0(-1.5,-0.6)$ & $-0.7(-1.4,0.0)$ \\
\hline
\end{tabular}

Table 3. Scenarios considered as a consequence of climate change in each river basin according to the increments found in Table 2. $T_{\text {max }}$ : maximum temperature $\left({ }^{\circ} \mathrm{C} \text { decade }{ }^{-1}\right)_{i} T_{\min }$ : minimum temperature $\left({ }^{\circ} \mathrm{C} \text { decade }{ }^{-1}\right)_{;} H R_{\max }$ : maximum relative humidity $\left(\% \text { decade }^{-1}\right)_{;} H R_{\min }$ : minimum relative humidity $\left(\%\right.$ decade $\left.^{-1}\right)$

\begin{tabular}{|c|c|c|c|c|c|c|c|c|c|c|c|c|}
\hline Scenario & Variable & North & Duero & Tajo & Guadiana & Guadalquivir & South & Segura & Júcar & Ebro & $\begin{array}{c}\text { Inner } \\
\text { Catalonia }\end{array}$ & $\begin{array}{c}\text { Balearic } \\
\text { Island }\end{array}$ \\
\hline 0 & $\begin{array}{c}T_{\max } \\
T_{\min } \\
H R_{\min } \\
H R_{\max }\end{array}$ & $\begin{array}{c}0.44 \\
0.36 \\
0 \\
0\end{array}$ & $\begin{array}{c}0.52 \\
0.48 \\
0 \\
0\end{array}$ & $\begin{array}{l}0.5 \\
0.39 \\
0 \\
0\end{array}$ & $\begin{array}{l}0.51 \\
0.97 \\
0 \\
0\end{array}$ & $\begin{array}{c}0.49 \\
0.55 \\
0 \\
0\end{array}$ & $\begin{array}{c}0.34 \\
0.59 \\
0 \\
0\end{array}$ & $\begin{array}{c}0.32 \\
0.72 \\
0 \\
0\end{array}$ & $\begin{array}{c}0.53 \\
0.61 \\
0 \\
0\end{array}$ & $\begin{array}{c}0.71 \\
0.28 \\
0 \\
0\end{array}$ & $\begin{array}{c}0.59 \\
0.57 \\
0 \\
0\end{array}$ & $\begin{array}{l}0.55 \\
0.7 \\
0 \\
0\end{array}$ \\
\hline 1 & $\begin{array}{c}T_{\max } \\
T_{\min } \\
H R_{\min } \\
H R_{\max }\end{array}$ & $\begin{array}{l}0.44 \\
0.36 \\
-0.1 \\
-0.9\end{array}$ & $\begin{array}{l}0.52 \\
0.48 \\
-0.5 \\
-1.6\end{array}$ & $\begin{array}{l}0.5 \\
0.39 \\
-1 \\
-0.3\end{array}$ & $\begin{array}{l}0.51 \\
0.97 \\
-1.5 \\
-2.2\end{array}$ & $\begin{array}{l}0.49 \\
0.55 \\
-1 \\
-1.1\end{array}$ & $\begin{array}{l}0.34 \\
0.59 \\
-2.5 \\
-0.7\end{array}$ & $\begin{array}{c}0.32 \\
0.72 \\
-1 \\
0.4\end{array}$ & $\begin{array}{l}0.53 \\
0.61 \\
-1.4 \\
-1.2\end{array}$ & $\begin{array}{l}0.71 \\
0.28 \\
-0.5 \\
-1.2\end{array}$ & $\begin{array}{l}0.59 \\
0.57 \\
-2.6 \\
-3.7\end{array}$ & $\begin{array}{l}0.55 \\
0.7 \\
-1 \\
-0.7\end{array}$ \\
\hline 2 & $\begin{array}{c}T_{\max } \\
T_{\min } \\
H R_{\min } \\
H R_{\max }\end{array}$ & $\begin{array}{l}0.64 \\
0.52 \\
-0.5 \\
-1.5\end{array}$ & $\begin{array}{l}0.78 \\
0.7 \\
-1.2 \\
-2.4\end{array}$ & $\begin{array}{l}0.77 \\
0.62 \\
-1.8 \\
-1.2\end{array}$ & $\begin{array}{l}0.8 \\
1.24 \\
-2.4 \\
-3.2\end{array}$ & $\begin{array}{l}0.74 \\
0.79 \\
-1.7 \\
-2.2\end{array}$ & $\begin{array}{l}0.54 \\
0.77 \\
-3.5 \\
-1.7\end{array}$ & $\begin{array}{l}0.5 \\
0.92 \\
-1.9 \\
-0.6\end{array}$ & $\begin{array}{l}0.75 \\
0.81 \\
-2.3 \\
-2.4\end{array}$ & $\begin{array}{l}0.98 \\
0.48 \\
-1.2 \\
-2.3\end{array}$ & $\begin{array}{l}0.78 \\
0.76 \\
-3.5 \\
-4.7\end{array}$ & $\begin{array}{l}0.75 \\
0.9 \\
-1.5 \\
-1.4\end{array}$ \\
\hline 3 & $\begin{array}{c}T_{\max } \\
T_{\min } \\
H R_{\min } \\
H R_{\max }\end{array}$ & $\begin{array}{l}0.23 \\
0.2 \\
0.3 \\
-0.3\end{array}$ & $\begin{array}{l}0.26 \\
0.26 \\
0.2 \\
-0.8\end{array}$ & $\begin{array}{c}0.22 \\
0.16 \\
-0.2 \\
0.7\end{array}$ & $\begin{array}{l}0.24 \\
0.7 \\
-0.7 \\
-1.2\end{array}$ & $\begin{array}{c}0.24 \\
0.3 \\
-0.3 \\
0\end{array}$ & $\begin{array}{c}0.15 \\
0.42 \\
-1.5 \\
0.3\end{array}$ & $\begin{array}{c}0.14 \\
0.52 \\
-0.1 \\
1.3\end{array}$ & $\begin{array}{c}0.31 \\
0.41 \\
-0.4 \\
0\end{array}$ & $\begin{array}{l}0.43 \\
0.09 \\
0.3 \\
0.1\end{array}$ & $\begin{array}{l}0.4 \\
0.38 \\
-1.7 \\
-2.7\end{array}$ & $\begin{array}{c}0.35 \\
0.5 \\
-0.6 \\
0\end{array}$ \\
\hline
\end{tabular}

this scenario, the highest $E T_{\mathrm{o}}$ increment values will be registered. Scenario 3 takes the smallest extremes of the CI of the slope estimator with CI of $95 \%$, i.e. the increments of the lowest temperatures and least negative relative humidity values. In this scenario, the lowest $E T_{\mathrm{o}}$ increment values will be registered.

\subsection{Characterization of national evapotranspiration}

Spain is a country of great climatic heterogeneity and changing temperature and humidity impacts on $E T_{\mathrm{o}}$ could vary widely, depending on the climatic region. The average $E T_{\mathrm{o}}$ in 2007 for the 338 stations was $1196 \mathrm{~mm}$ (Fig. 2a). The minimum $E T_{\mathrm{o}}$ values were observed in northwestern Spain $(753 \mathrm{~mm})$ and the maximum values occurred in the Guadalquivir valley, where the mean was close to $1759 \mathrm{~mm}$.

Precipitation was irregularly distributed, reaching average values ranging from $1600 \mathrm{~mm}$ in the northwest to $250 \mathrm{~mm}$ in the southeast.

In terms of annual accumulated precipitation, 2007 was somewhat dry for the entire Spanish peninsula, with an average estimated precipitation of $608 \mathrm{~mm}$ compared with $650 \mathrm{~mm}$ for the reference period 1971-2000. Precipitation values for 2007 were normal in the Mediterranean region, with an estimated average precipitation of $575 \mathrm{~mm}$, and somewhat dry in the Atlantic (629 mm).

Considering all 4 scenarios, the greatest annual change in the increment of $E T_{\mathrm{o}}$ was $616 \mathrm{~mm}$ in Scenario 2 for the Ebro River basin, and the lowest was $52 \mathrm{~mm}$ for Scenario 3 for the Segura River Basin 


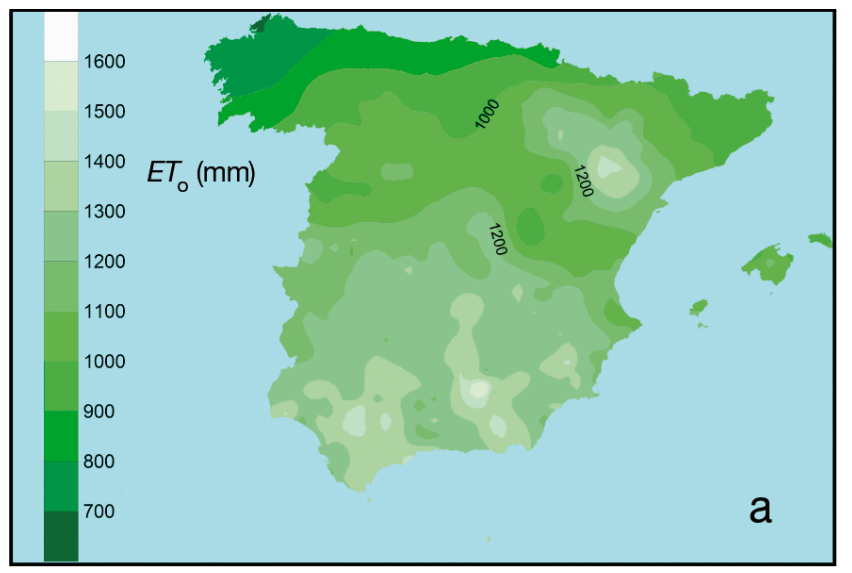

Fig. 2. (a) Reference evapotranspiration $\left(E T_{0}\right)$ in Spain for the reference year 2007 and increases at the end of the 21st century according to Scenarios 0 (b), 1 (c), 2 (d) and 3 (e)
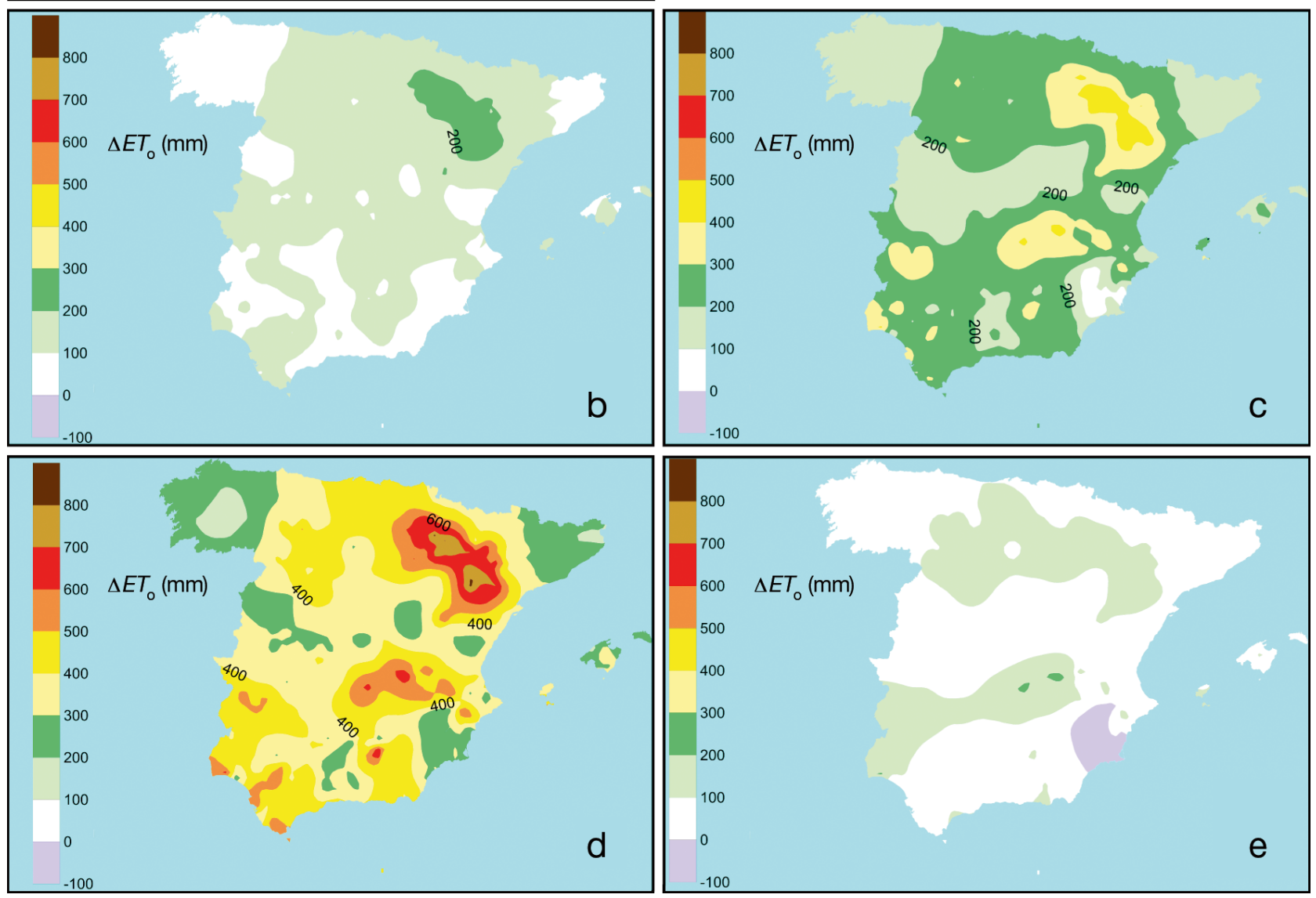

(Fig. 2). Scenario 2 was the most unfavorable for Spain, due to the greater water need.

In Scenario 2, the greatest increase and difference in $E T_{\mathrm{o}}$ observed between different river basins was $400 \mathrm{~mm}$ (Fig. 2d-one river basin with $700 \mathrm{~mm}$ and another with $300 \mathrm{~mm}$, approx.). Scenario 3 presented the least variability compared to the current situation, with an annual average increase in $E T_{0}$ of $80 \mathrm{~mm}$. In all of the given scenarios, the river basin most affected by the changes was the Ebro River basin, which always showed increases of $>100 \mathrm{~mm}$.

Table 4 shows the monthly $E T_{\mathrm{o}}$ data and the corresponding increases in $E T_{\mathrm{o}}$ for the given scenarios (see Table 3). The most affected months were May, June, July and August, while November, December and January were the least affected by the climate change.

Scenarios $0,1,2$ and 3 and resulted in increases in $E T_{\mathrm{o}}$ of $11 \%(128 \mathrm{~mm}), 21 \%(257 \mathrm{~mm}), 36 \%(430 \mathrm{~mm})$ and $7 \%(80 \mathrm{~mm})$, respectively. The year 2007 has a variation of $+0.4^{\circ} \mathrm{C}$ with respect to the average of the 1971-2000 period (AEMET 2010). Applying the correction of $-0.4^{\circ} \mathrm{C}$ to the maximum and minimum tem- 
Table 4. Mean monthly reference evapotranspiration $\left(E T_{\mathrm{o}}\right)$ and increments $\left(\Delta E T_{\mathrm{o}} ; \mathrm{mm}, \%\right)$ of the different scenarios. Data are based on 338 stations using a reference year of 2007

\begin{tabular}{|c|c|c|c|c|c|c|c|c|c|}
\hline \multirow{2}{*}{ Month } & \multirow{2}{*}{$\begin{array}{c}E T_{\mathrm{o}} \\
(\mathrm{mm})\end{array}$} & & \multicolumn{4}{|c|}{$\Delta E 1_{\mathrm{o}}$} & \\
\hline & & $\begin{array}{l}\text { Scenar } \\
(\mathrm{mm})\end{array}$ & $\begin{array}{r}\text { ario } 0 \\
(\%)\end{array}$ & $\begin{array}{l}\text { Scena } \\
(\mathrm{mm})\end{array}$ & $\begin{array}{r}\text { rio } 1 \\
(\%)\end{array}$ & $\begin{array}{l}\text { Scenar } \\
(\mathrm{mm})\end{array}$ & $\begin{array}{r}\text { rio } 2 \\
(\%)\end{array}$ & $\begin{array}{l}\text { Scenar } \\
(\mathrm{mm})\end{array}$ & $\begin{array}{r}\text { rio } 3 \\
(\%)\end{array}$ \\
\hline Jan & 31.5 & 4.1 & 13 & 11.2 & 35 & 20.3 & 64 & 2.7 & 8 \\
\hline Feb & 48.1 & 7.3 & 15 & 16.9 & 35 & 29.8 & 62 & 4.9 & 10 \\
\hline Mar & 87.5 & 13.7 & 16 & 25.5 & 29 & 43.1 & 49 & 8.2 & 9 \\
\hline Apr & 91.6 & 11.7 & 13 & 21.4 & 23 & 35.8 & 39 & 7.4 & 8 \\
\hline May & 144.6 & 16.5 & 11 & 29.4 & 20 & 48.4 & 33 & 10.1 & 7 \\
\hline Jun & 166.3 & 15.7 & 9 & 28.4 & 17 & 46.2 & 28 & 9.8 & 6 \\
\hline Jul & 198.0 & 16.6 & 8 & 30.7 & 16 & 48.7 & 25 & 10.2 & 5 \\
\hline Aug & 167.4 & 14.5 & 9 & 28.8 & 17 & 46.7 & 28 & 9.1 & 5 \\
\hline Sep & 113.7 & 10.4 & 9 & 21.8 & 19 & 36.4 & 32 & 6.7 & 6 \\
\hline Oct & 71.4 & 7.3 & 10 & 16.8 & 24 & 29.1 & 41 & 4.7 & 7 \\
\hline Nov & 45.5 & 5.7 & 13 & 13.8 & 30 & 24.0 & 53 & 3.6 & 8 \\
\hline Dec & 30.5 & 4.1 & 13 & 11.7 & 38 & 21.5 & 70 & 2.7 & 9 \\
\hline Annual & 1196 & 128 & 11 & 257 & 21 & 430 & 36 & 80 & 7 \\
\hline
\end{tabular}

crements in $E T_{\mathrm{o}}$ for this month fluctuated from $78 \mathrm{~mm}$ for the Ebro River valley in Scenario 2 (Fig. 4d) to near zero for the Segura River basin in Scenario 3 (Fig. 4e).

Fig. 5 shows the relationship between the current (actual, $E T_{\text {oaa }}$ ) and future $\left(E T_{\text {oaf }}\right)$ annual $E T_{\text {o }}$ for the various scenarios for all 338 stations. In all cases, $E T_{\text {oaf }}$ was greater than $E T_{\text {oaa }}$ and the slope of the regression between $E T_{\text {oaa }}$ and $E T_{\text {oaf }}$ was $>1$. In Scenario 0 , a $1.00 \mathrm{~mm}$ increase in $E T_{\text {oaa }}$ resulted in a $1.107 \mathrm{~mm}$ increase in $E T_{\text {oaf, }}$ whereas in Scenario 2 a $1.00 \mathrm{~mm}$ increase in $E T_{\text {оаa }}$ resulted in a $1.36 \mathrm{~mm}$ increase in $\mathrm{ET}_{\text {oaf. }}$ For the most probable future scenario (Scenario 1), there was an annual increase of $21 \%$ in $E T_{\mathrm{o}}$. peratures for each Scenario posed at the end of the 21st century, we get increases of $E T_{\mathrm{o}}$ of $10,20,35$ and $6 \%$ for Scenarios 0, 1, 2 and 3, respectively, which is to say, a drop of $1 \%$ in the increase of $E T_{\text {o }}$ with respect to the 2007 scenarios. In absolute terms, $E T_{\text {o }}$ was highest in the months with the highest $E T_{\mathrm{o}}$ increments (Figs. 3 \& 4). In relative terms, the winter months showed the greatest relative increase. May had the highest absolute increase in $E T_{\text {or }}$, but July had the highest overall mean $E T_{\text {o }}$ rate.

The summer months had the highest water needs, e.g. $45 \%$ of the annual $E T_{\mathrm{o}}$ occurred in June, July and August. July had the highest mean annual $E T_{0}$ at $189 \mathrm{~mm}$, which represents $16 \%$ of the annual $E T_{\mathrm{o}}$. Because the greatest water need for crops occurs in July, any changes in the monthly $E T_{\mathrm{o}}$ rate could affect the distribution and/or sizing of the irrigation system. Fig. 3 shows the increases in $E T_{\mathrm{o}}$ that will occur in Spain as a consequence of the 4 scenarios presented for the month of January, and Fig. 4 shows these increases for July.

A greater increase in $E T_{\mathrm{o}}$ in January takes place in northern Spain compared with southern Spain (Fig. 3). The most vulnerable areas are the Ebro River valley, some points on the coast of the Cantabrian Sea and the south of Spain. In Scenarios 0 and 3, values of $E T_{\mathrm{o}}$ are reached with increases close to zero (Fig. 3b,e), which will not affect the current $E T_{\mathrm{o}}$ situation for January. Scenario 2 resulted in $E T_{\mathrm{o}}$ increments near $40 \mathrm{~mm}$ in the Ebro River valley, whereas in the majority of the peninsula increments were near $20 \mathrm{~mm}$ (Fig. 3d).

Like January (Fig. 3), the area most vulnerable to climate change impacts on $E T_{\mathrm{o}}$ during July is northern Spain (Fig. 4), particularly the Ebro River valley. The in-

\subsection{Characterization of river basin evapotranspiration}

Spain divides into 11 major river basins. The Ebro River basin had the greatest annual increase in $E T_{\mathrm{o}}$ in Scenarios 0 (215 mm), 1 (373 mm) and 2 (619 mm). This river basin was least affected by Scenario 3. The Guadiana River basin was most affected by Scenario 3 (168 mm). The Segura River basin was least affected by Scenarios 0, 1 and 3, with an annual change of +75 , +96 and $-52 \mathrm{~mm}$, respectively. The Northern River basin was least affected by the change in Scenario 2 (213 mm).

Table 5 displays the monthly $E T_{0}$ for each river basin. The river basin with the greatest $E T_{0}$ is the Guadalquivir (1309 mm). For all river basins, the month with the greatest $E T_{\mathrm{o}}$ is July, with values ranging from 126 to $220 \mathrm{~mm}$.

The months most affected by the increase in $E T_{\mathrm{o}}$ for all scenarios were May, June and July in all river basins. The months least affected by these changes were November, December and January, depending on the river basin and the scenario.

Future monthly $E T_{\text {o }}\left(E T_{\text {omf }}\right)$ was estimated using a linear adjustment between the current monthly $E T_{\mathrm{o}}$ $\left(E T_{\text {oma }}\right)$ and the $E T_{\text {omf }}$ (Table 6). The Northern River basin is not shown in the results because of the low number of stations. The Inner Catalonia River basin is also not shown because there were no stations for the simulation scenarios. In Scenario 2, the monthly increase in $E T_{\text {o }}$ ranged from $\sim 10$ to $25 \%$, whereas in Scenario 3 , the increase ranged from $\sim 0$ to $7 \%$. Scenarios 0 and 1 resulted in intermediate increases in $E T_{\text {o }}$ with respect to Scenarios 2 and 3. The Ebro River basin 


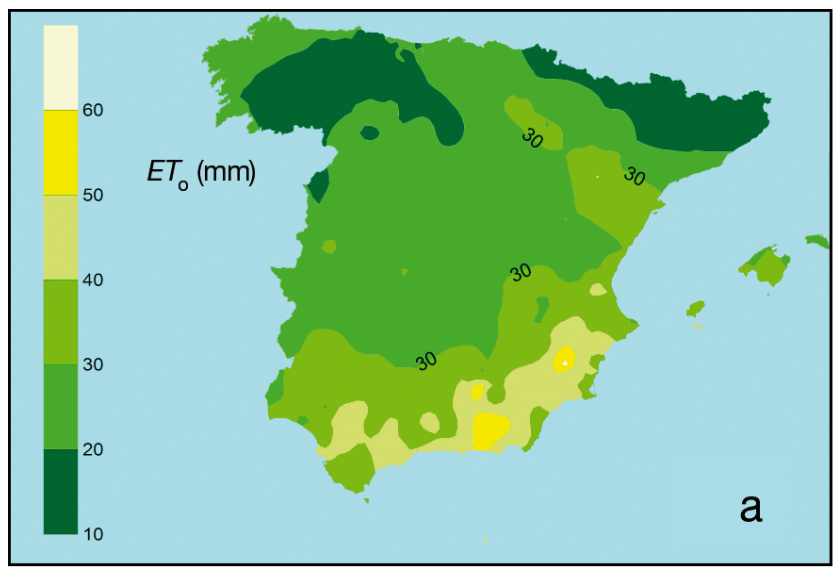

Fig. 3. (a) Reference evapotranspiration $\left(E T_{\mathrm{o}}\right)$ in January for the reference year 2007 and increases in January according to scenarios 0 (b), 1 (c), 2 (d) and 3 (e)
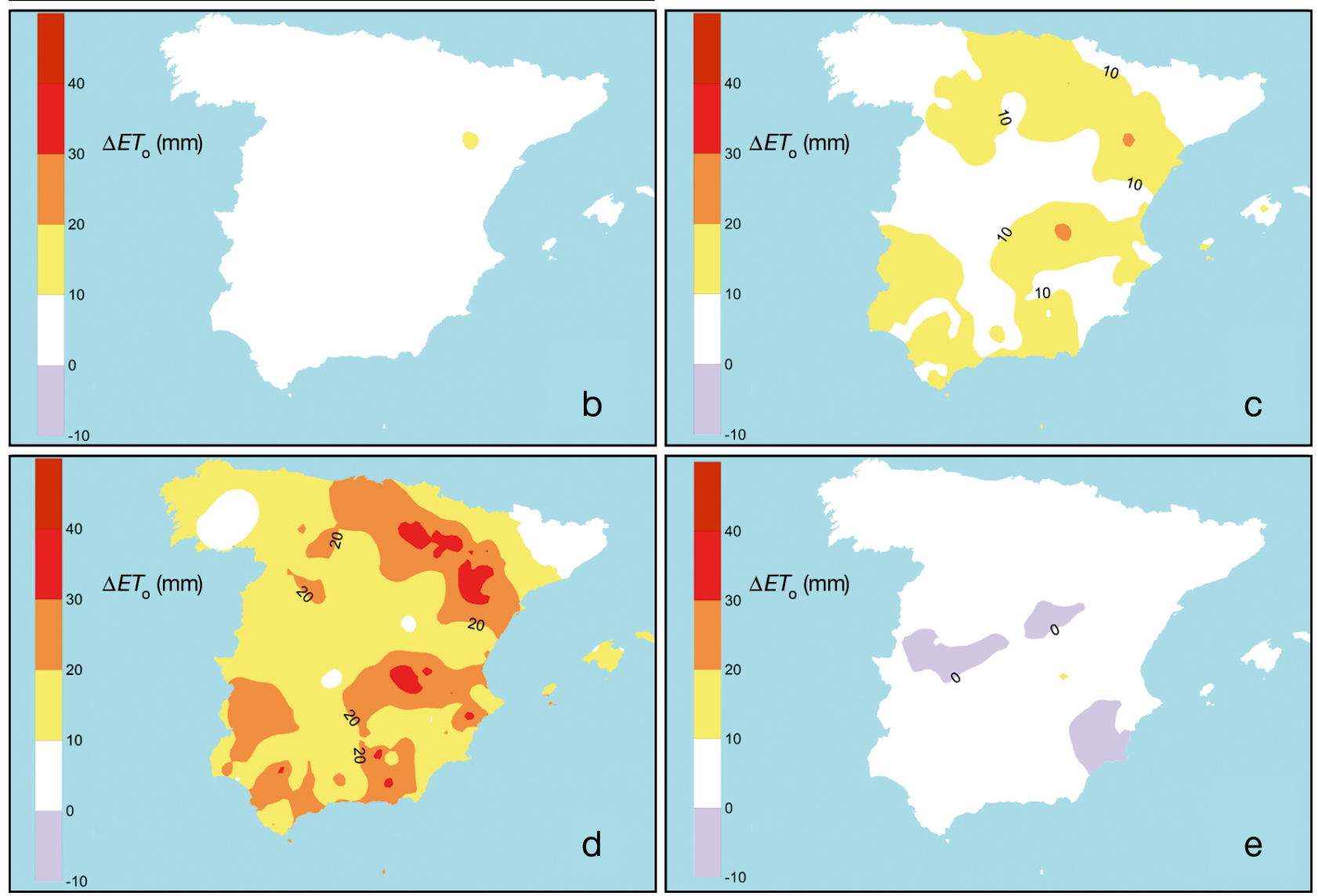

was the most susceptible to climate change resulting from Scenarios 0, 1 and 2, with a monthly increase in $E T_{0}$ of 12,17 and $25 \%$, respectively. For Scenario 3, the increase in $E T_{0}$ ranged from 0 to $7 \%$ for all river basins.

\section{DISCUSSION}

Some authors have reported that evapotranspiration over grassland increased by $17 \%$ with air temperature increases of $3^{\circ} \mathrm{C}$ (Martin et al. 1989, Rosenberg et al.
1989). However, the present study showed that the increase in evapotranspiration due to temperature rise can be offset with increasing humidity. The increase in maximum and minimum temperatures that will occur in Spain at the end of the 21st century according to the trend of the 1973-2002 period will be in increments of between 0.3 and $0.7^{\circ} \mathrm{C}$ decade $^{-1}$, depending on the area. Authors such as Brunet et al. (2007) have indicated increases in the maximum and minimum temperatures of around $0.5^{\circ} \mathrm{C}$ decade ${ }^{-1}$ during the $1973-$ 2005 period, very similar to the values we obtained for 


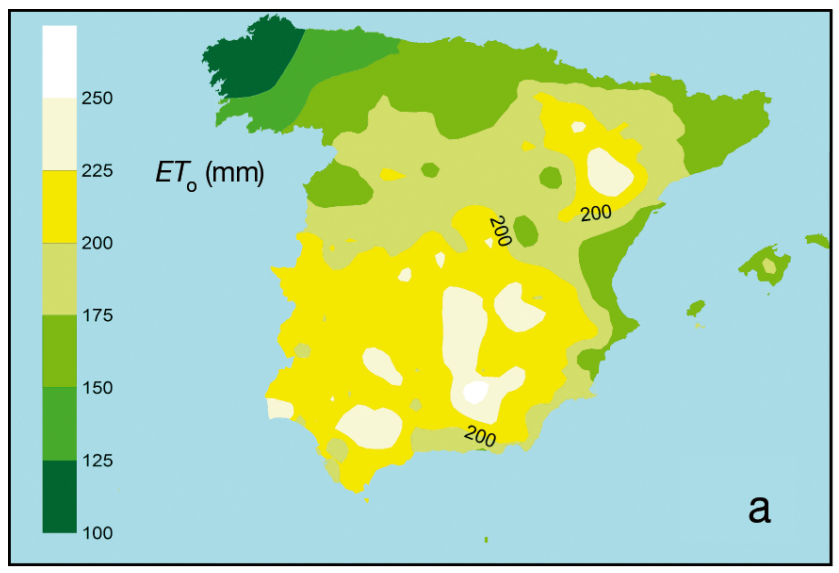

Fig. 4. (a) Reference evapotranspiration $\left(E T_{0}\right)$ in July for the reference year 2007 and increases at the end of the 21st century in July according to scenarios 0 (b), 1 (c), 2 (d) and 3 (e)
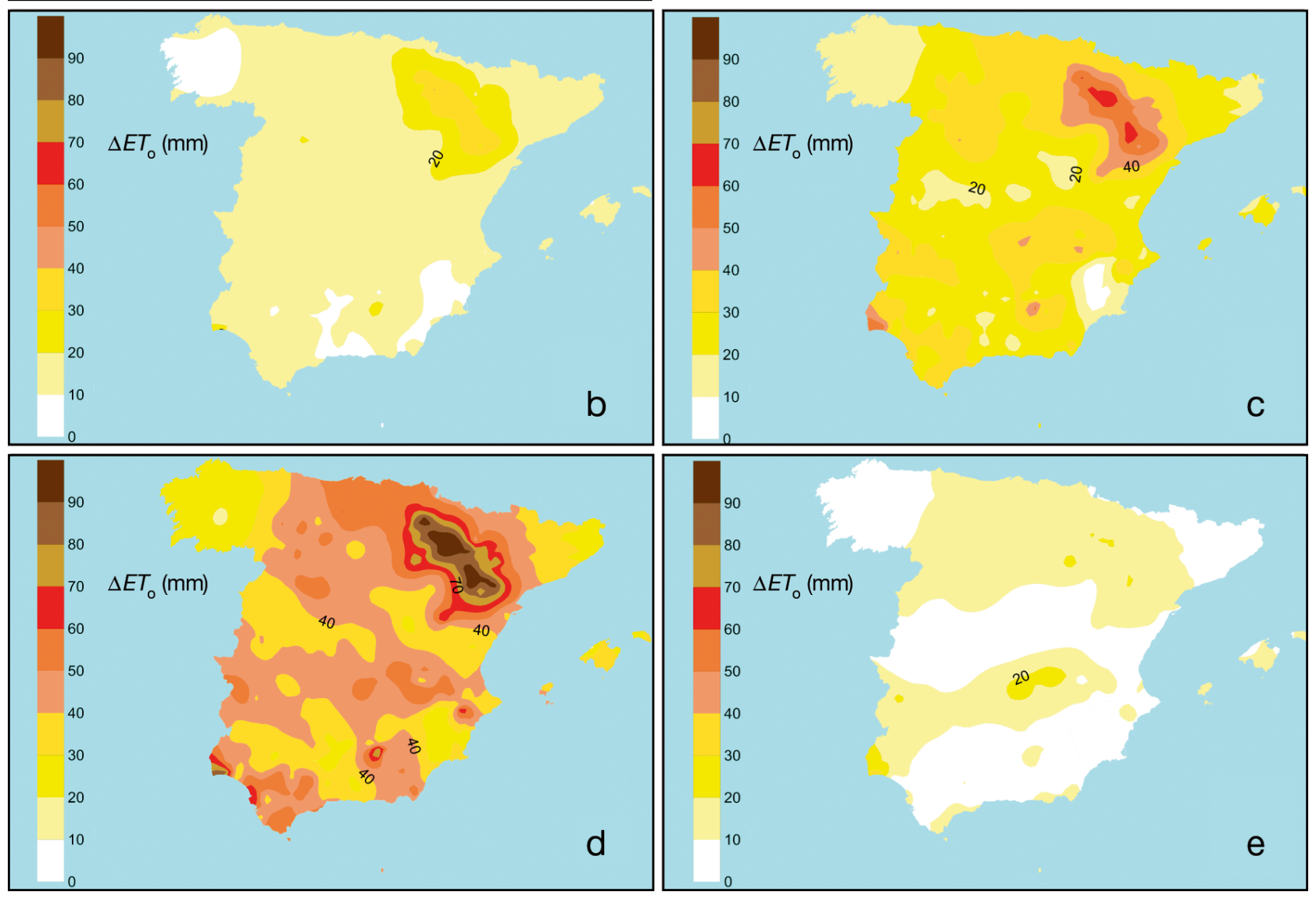

the 1973-2002 period. There have been several studies specific to Spain on the regional trends in maximum and minimum temperatures. Ramos et al. (2008) obtained trends similar to those found in the present study for the Ebro River basin area and Inner Catalonia, with average increments in maximum and minimum temperature of $0.5^{\circ} \mathrm{C}$ decade $^{-1}$. Del Rio et al. (2007) showed trends lower than those observed in the present study in the Duero River basin, with increments in maximum and minimum temperature of $0.2^{\circ} \mathrm{C}$ decade $^{-1}$ for the 1961-1997 period. However, when this period is compared with that of the present study (1973-2002), this tendency increases (Brunet et al. 2007).

There is controversy with respect to changes in atmospheric humidity as a consequence of climate change, although the majority of authors suggest that relative humidity will remain more or less constant. According to Szilagyi et al. (2001), although temperature has increased, the vapour pressure deficit has remained constant during recent decades. Authors such as Ross \& Elliott (2001), Soden et al. (2005) and 

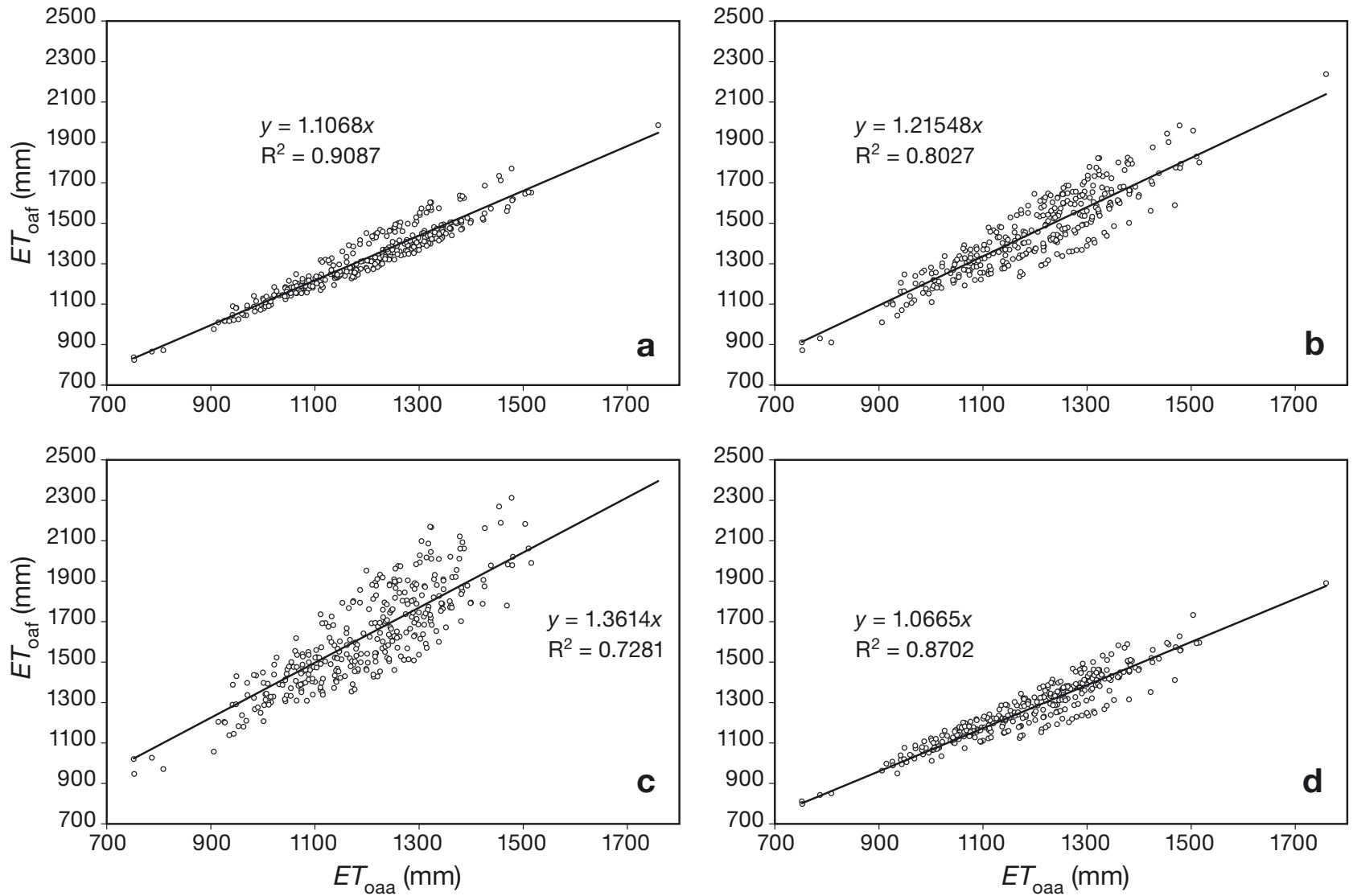

Fig. 5. Relationship between the current $\left(E T_{\text {oaa }}\right)$ and future $\left(E T_{\text {oaf }}\right)$ annual reference evapotranspiration according to scenarios 0 (a), 1 (b), 2 (c) and 3 (d)

Table 5. Monthly reference evapotranspiration $\left(E T_{\mathrm{o}}\right)$ for the different river basins. Data are based on 338 stations using a reference year of 2007

\begin{tabular}{|lrrrrrrrrrr|}
\hline Month & North & Duero & Tajo & Guadiana & Guadalquivir & South & Segura & Júcar & $\begin{array}{r}\text { Ebro } \\
\text { Balearic } \\
\text { Island }\end{array}$ \\
\hline Jan & & & & & & & & & & \\
Feb & 20.67 & 20.85 & 26.61 & 28.45 & 37.62 & 42.19 & 43.73 & 34.51 & 27.62 & 32.20 \\
Mar & 53.82 & 39.02 & 43.63 & 46.04 & 46.74 & 59.31 & 60.93 & 53.05 & 47.50 & 47.15 \\
Apr & 83.78 & 70.70 & 84.14 & 90.61 & 94.43 & 101.58 & 103.45 & 90.92 & 83.90 & 76.00 \\
May & 95.02 & 120.60 & 135.35 & 147.60 & 151.08 & 158.03 & 167.91 & 149.92 & 143.72 & 143.86 \\
Jun & 104.21 & 144.53 & 159.99 & 175.11 & 180.35 & 181.64 & 181.70 & 160.81 & 167.65 & 153.47 \\
Jul & 126.07 & 179.07 & 203.94 & 219.59 & 217.89 & 199.46 & 197.16 & 178.56 & 205.28 & 167.58 \\
Aug & 112.76 & 153.44 & 178.84 & 187.33 & 186.19 & 170.71 & 163.12 & 146.03 & 171.65 & 139.19 \\
Sep & 87.84 & 110.66 & 116.85 & 121.35 & 124.12 & 115.33 & 109.88 & 97.67 & 120.19 & 96.61 \\
Oct & 50.19 & 57.38 & 69.60 & 78.38 & 85.65 & 79.36 & 70.77 & 59.81 & 76.51 & 58.66 \\
Nov & 24.88 & 34.61 & 39.67 & 46.49 & 53.60 & 51.01 & 49.24 & 38.67 & 52.93 & 38.52 \\
Dec & 17.73 & 18.60 & 24.52 & 28.53 & 35.20 & 41.16 & 42.50 & 31.57 & 30.20 & 31.45 \\
Annual & 809 & 1042 & 1175 & 1265 & 1309 & 1295 & 1284 & 1123 & 1221 & 1069 \\
\hline
\end{tabular}

Trenberth et al. (2007) have indicated that humidity will remain constant. Rowell \& Jones (2006) suggested that, in the months of June through August, the relative humidity could diminish by 10 to $20 \%$ by the end of the 21st century. In our case, the trends in relative humidity are not as homogenous as trends in temperature, but we observed some downward trends in the average values of maximum and minimum relative 
Table 6 . Values of the conversion coefficient $b$, which relates the future monthly reference evapotranspiration $\left(E T_{\text {omf }}\right)$ with the current monthly reference evapotranspiration $\left(E T_{\text {oma }}\right)$ according to the equation $E T_{\text {omf }}=b E T_{\text {oma }} \cdot R^{2}=0.99$ for the different scenarios

\begin{tabular}{|c|c|c|c|c|c|c|c|c|c|}
\hline \multirow{2}{*}{ Scenario } & & & & & \multirow{2}{*}{$\begin{array}{l}\text { Basin } \\
\text { South }\end{array}$} & \multirow[b]{2}{*}{ Segura } & \multirow[b]{2}{*}{ Júcar } & \multirow[b]{2}{*}{ Ebro } & \multirow[b]{2}{*}{$\begin{array}{c}\text { Balearic } \\
\text { Island }\end{array}$} \\
\hline & Duero & Tajo & Guadiana & Guadalquivir & & & & & \\
\hline 0 & 1.09 & 1.07 & 1.07 & 1.06 & 1.05 & 1.05 & 1.07 & 1.12 & 1.07 \\
\hline 1 & 1.14 & 1.08 & 1.12 & 1.10 & 1.10 & 1.05 & 1.11 & 1.17 & 1.09 \\
\hline 2 & 1.20 & 1.14 & 1.14 & 1.14 & 1.15 & 1.10 & 1.16 & 1.25 & 1.13 \\
\hline 3 & 1.07 & 1.01 & 1.07 & 1.03 & 1.04 & 1.00 & 1.05 & 1.06 & 1.05 \\
\hline
\end{tabular}
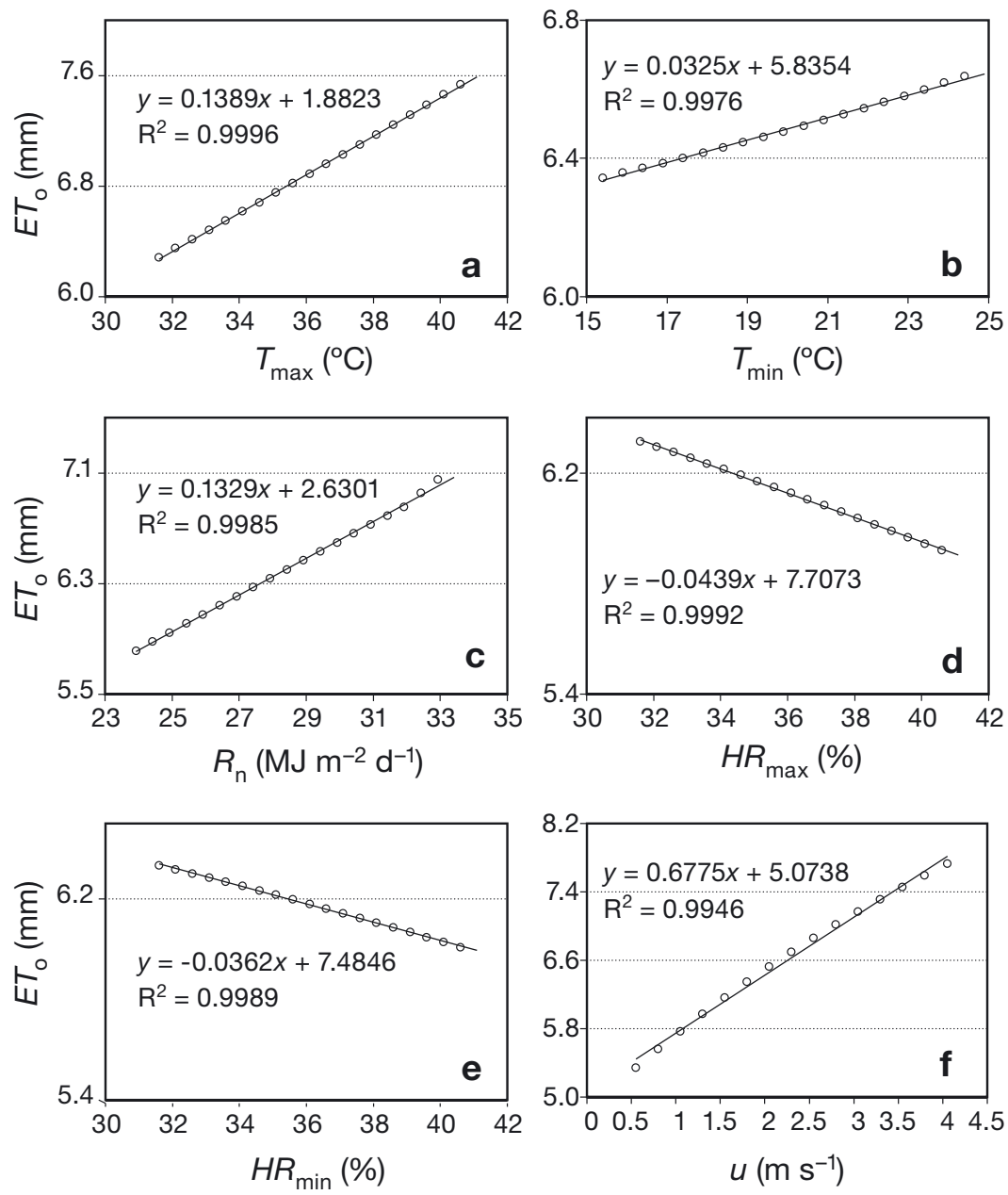

Fig. 6. Relationship between reference evapotranspiration $\left(E T_{\mathrm{o}}\right)$ and the different climate variables. (a) Maximum temperature, (b) minimum temperature, (c) net radiation at the surface, (d) maximum relative humidity, (e) minimum relative humidity and (f) wind speed. The variable on the $x$-axis of each panel is increased, while all other variables are held constant at: $T_{\max }=32^{\circ} \mathrm{C}_{\text {; }}$ $T_{\min }=15^{\circ} \mathrm{C}_{i} R_{\mathrm{n}}=28 \mathrm{MJ} \mathrm{m}^{-2} \mathrm{~d}^{-1} ; u=1.8 \mathrm{~m} \mathrm{~s}^{-1} ; H R_{\max }=90 \%$; and $H R_{\min }=30 \%$
\& 4) and some areas on the southern coast. In general, the Segura River basin had $E T_{\mathrm{o}}$ increments lower than in other river basins. This is because the upward trends in temperature and relative humidity were lower due to the location of the 3 stations used, which were very close to one another and to the sea.

To explain how the different scenarios affect each river basin, we first analysed the individual contribution of the different climate variables to the $E T_{\text {o }}$ value, and considered simulations in which only the analysed variable changed and the others were held constant (Fig. 6). Hypothetically, we considered normal values for a summer day where $T_{\max }=$ $32^{\circ} \mathrm{C}, T_{\min }=15^{\circ} \mathrm{C}, R_{\mathrm{n}}=28 \mathrm{MJ} \mathrm{m}^{-2} \mathrm{~d}^{-1}$, $u=1.8 \mathrm{~m} \mathrm{~s}^{-1}, H R_{\max }=90 \%$ and $H R_{\min }=$ $30 \%$, and measured the effect of increases of each variable on $E T_{0}$. Results indicate that $E T_{\mathrm{o}}$ is directly proportional to each of the variables. For all variables except relative humidity, $E T_{\mathrm{o}}$ increased with the variable. Wind speed had the greatest impact on $E T_{0}$ : increments of a unit of wind velocity produced an increase of $0.67 \mathrm{~mm}$ in $E T_{\mathrm{o}}$.

Using Eq. (1), we then separated $E T_{\text {o }}$ into diabatic or radiative and adiabatic or convective (Monteith \& Unsworth 2008) components:

$$
\begin{gathered}
E T_{\mathrm{o}}=E T_{\mathrm{od}}+E T_{\mathrm{oa}}= \\
\frac{0.408 \Delta\left(R_{\mathrm{n}}-G\right)}{\Delta+\gamma\left(1+0.34 u_{2}\right)}+\frac{\gamma \frac{900}{T+273} u_{2}\left(e_{\mathrm{s}}-e_{\mathrm{a}}\right)}{\Delta+\gamma\left(1+0.34 u_{2}\right)}
\end{gathered}
$$

humidities under $3 \%$ per decade, depending on the region (Table 2). In many cases, the reduction in humidity is tied to a reduction in precipitation (Rowell \& Jones 2006).

The regions of Spain that were the most susceptible to increasing $E T_{\text {o }}$ were the Ebro River basin (Figs. 2, 3 where $E T_{\text {od }}$ and $E T_{\text {oa }}$ are the diabatic and adiabatic reference evapotranspiration components, respectively.

Focusing on the adiabatic component, wind speed was multiplied by the vapour pressure deficit (VPD = $e_{\mathrm{s}}-e_{\mathrm{a}}$ ), so the effect of the wind speed on $E T_{\mathrm{o}}$ is less for smaller VPD. Increasing the relative humidity caused a 
Table 7. Annual daily means of the climate variables affecting reference evapotranspiration $E T_{\mathrm{o}}$. $T_{\max }$ : maximum temperature $\left({ }^{\circ} \mathrm{C}\right.$ decade $\left.{ }^{-1}\right) ; T_{\min }$ : minimum temperature; $H R_{\max }$ : maximum relative humidity; $H R_{\min }$ : minimum relative humidity; $u$ : wind speed; $R_{\mathrm{n}}$ : net radiation at the surface; $e_{\mathrm{s}}-e_{\mathrm{a}}$ : actual minus saturation vapour pressure

\begin{tabular}{|lrrrrrrr|}
\hline River basin & $\begin{array}{c}T_{\max } \\
\left({ }^{\circ} \mathrm{C}\right)\end{array}$ & $\begin{array}{c}T_{\min } \\
\left({ }^{\circ} \mathrm{C}\right)\end{array}$ & $\begin{array}{c}H R_{\max } \\
(\%)\end{array}$ & $\begin{array}{c}H R_{\min } \\
(\%)\end{array}$ & $\begin{array}{c}u \\
\left(\mathrm{~m} \mathrm{~s}^{-1}\right)\end{array}$ & $\begin{array}{c}R_{\mathrm{n}} \\
\left(\mathrm{MJ} \mathrm{m}^{-2} \mathrm{~d}^{-1}\right)\end{array}$ & $\begin{array}{c}e_{\mathrm{s}}-e_{\mathrm{a}} \\
(\mathrm{kPa})\end{array}$ \\
\hline Duero & 17.3 & 3.6 & 92.0 & 43.9 & 1.9 & 16.7 & 0.73 \\
Tajo & 21.0 & 6.8 & 86.1 & 38.0 & 1.5 & 17.2 & 1.04 \\
Guadiana & 21.6 & 8.2 & 86.1 & 38.6 & 1.7 & 18.2 & 1.08 \\
Guadalquivir & 23.2 & 9.8 & 83.9 & 37.1 & 1.6 & 18.3 & 1.20 \\
South & 22.8 & 11.3 & 82.2 & 38.3 & 1.5 & 18.4 & 1.10 \\
Segura & 22.7 & 11.0 & 85.0 & 39.2 & 1.7 & 17.5 & 1.06 \\
Júcar & 21.7 & 9.8 & 86.7 & 41.0 & 1.4 & 16.2 & 0.96 \\
Ebro & 20.0 & 7.1 & 87.8 & 41.2 & 2.4 & 16.1 & 0.92 \\
Balearic Island & 22.2 & 11.1 & 92.0 & 49.0 & 1.4 & 15.5 & 0.83 \\
\hline
\end{tabular}

February will have increases $<30 \mathrm{~mm}$ $\mathrm{mo}^{-1}$ under the most unfavorable conditions (greatest increase in $E T_{0}$, Scenario 2).

It is projected that precipitation in Spain will decrease by $30 \%$ in the south and $5 \%$ in the north (Rodriguez-Puebla \& Nieto 2009). From a water management point of view, considering that the most decisive factors in agricultural water management are evapotranspiration and precipitation, the reduced precipitation and higher evapotranspiration could aggravate water problems in Spain. reduction in VPD and reduced $E T_{0}$. With the given scenarios, which modify the temperature and relative humidity, the adiabatic component was the most affected and, if the wind velocities are also elevated, these increases are even greater, in the case of the Ebro River basin.

Table 7 shows the annual daily averages of the different climate variables, which explain the behavior of the river basins as a result of the different climate change scenarios. The Ebro River basin had the greatest wind speed, which explains its susceptibility to scenarios.

The months most affected by the scenarios are May, June, July and August. In these months, the $E T_{\text {od }}$ is higher due to radiation. In May and March, many meteorological stations experience their highest wind speeds.

\section{CONCLUSIONS}

Generally, the annual $E T_{\mathrm{o}}$ at the end of the 21st century will likely increase, but the impact on $E T_{\mathrm{o}}$ depends on the magnitude of change in air temperature and relative humidity. Considering the average trends of the different river basins, we can affirm that the annual increase in $E T_{\mathrm{o}}$ in Spain is $257 \mathrm{~mm}$, an increase of $21 \%$. These increases in $E T_{\mathrm{o}}$ can fluctuate between 80 and $430 \mathrm{~mm}$, depending on the scenarios. The biggest increase will be in regions which have strong winds, e.g. the Ebro River valley and some points on the southern coast of Spain. The increases will be more noticeable in the months of May, June, July and August, with increases of $<80 \mathrm{~mm} \mathrm{mo}^{-1}$ under the most unfavorable conditions (greatest increase in $E T_{0}$, Scenario 2). December, January and
Acknowledgments. Thanks are due to José Vicente Moreno of Agencia Estatal de Meteorología (AEMET) for his assistance with the elaboration and manipulation of the map of Spain in Surfer ${ }^{\circledR}$, and to manuscript reviewers for their useful comments, which greatly improved this paper.

\section{LITERATURE CITED}

AEMET (Agencia estatal de Meteorología) (2010) Resumen anual climatológico del año 2007. AEMET, Madrid. Available at: www.aemet.es

Allen RG, Pereira LS, Raes D, Smith M (1998) Crops evapotranspiration. Guidelines for computing crop requirements. Irrigations and Drainage Paper 56. FAO, Rome

Allen RG, Pruitt WO, Wright JL, Howell TA and others (2006) A recommendation on standardized surface resistance for hourly calculation of reference ET0 by the FAO-56 Penman-Monteith method. Agric Water Manag 81:1-22

Anderson J, Chung F, Anderson M, Brekke L and others (2008) Progress on incorporating climate change into management of California's water resources. Clim Change 87 (Suppl 1):91-108

Brohan P, Kennedy JJ, Harris I, Tett SFB, Jones PD (2006) Uncertainty estimates in regional and global observed temperature changes: a new dataset from 1850. J Geophys Res 111:D12106 doi:10.1029/2005JD006548

Brunet M, Jones PD, Sigró J, Saladié O and others (2007) Temporal and spatial temperature variability and change over Spain during 1850-2005. J Geophys Res 112:D12117 doi:10.1029/2006JD008249

Bürger CM, Kolditz O, Fowler HF, Blenkinsop S (2007) Future climate scenarios and rainfall-runoff modelling in the Upper Gallego catchment (Spain). Environ Pollut 148: 842-854

Burn DH, Hesch NM (2007) Trends in evaporation for the Canadian prairies. J Hydrol 336:61-76

Christensen JH, Hewitson B, Busuioc A, Chen A and others (2007) Regional climate projections. In: Solomon S, Qin D, Manning $\mathrm{M}$, Chen $\mathrm{Z}$ and others (eds) Climate change 2007: the physical science basis. Contribution of Working Group I to the Fourth Assessment Report of the Inter- 
governmental Panel on Climate Change. Cambridge University Press, Cambridge

Cohen S, Ianetz A, Stanhill G (2002) Evaporative climate changes at Bet Dagan, Israel, 1964-1998. Agric Meteorol 111:83-91

Da Silva VPR (2004) On climate variability in northeast of Brazil. J Arid Environ 58:575-596

- De Luís M, Raventós J, González-Hidalgo JC, Sánchez JR, Cortina J (2000) Spatial analysis of rainfall trends in the region of Valencia (East Spain). Int J Climatol 20:1451-1469

Del Rio S, Fraile R, Herrero L, Penas A (2007) Analysis of recent trends in mean maximum and minimum temperatures in a region of the NW of Spain (Castilla y León). Theor Appl Climatol 90:1-12

Esteban-Parra MJ, Pozo-Vázquez D, Rodrigo FS, Castro-Díez Y (2003) Temperature and precipitation variability and trends in northern Spain in the context of the Iberian Peninsula climate. In: Bolle HJ (ed) Mediterranean climate. Springer, Berlin, p 259-276

Fink AH, Brücher T, Krüger A, Leckebusch GC, Pinto JG, Ulbrich U (2004) The 2003 European summer heatwaves and drought - synoptic diagnosis and impacts. Weather 59:209-216

Giorgi F, Hewitson B, Christensen J, Fu C and others (2001) Regional climate information: evaluation and projections. In: Houghton JT, Ding Y, Griggs DJ, Noguer M and others (eds) Climate change 2001: the scientific basis. Contribution of Working Group I to the Third Assessment Report of the Intergovernmental Panel on Climate Change. Cambridge University Press, Cambridge, p 583-638

Gleick PH (1986) Methods for evaluating the regional hydrologic impacts of global climatic changes. J Hydrol 88: 97-116

Goyal RK (2004) Sensivity of evapotranspiration to global warming: a case study of arid zone of Rajasthan (India). Agric Water Manag 69:1-11

> Hansen JE, Ruedy R, Sato M, Imhoff M and others (2001) A closer look at United States and global surface temperature change. J Geophys Res 106:23947-23963

IPCC (2007) Summary for policymakers. In: Solomon S, Qin D, Manning M, Chen Z and others (eds) Climate change 2007: the physical science basis. Contribution of Working Group I to the Fourth Assessment Report of the Intergovernmental Panel on Climate Change. Cambridge University Press, Cambridge

> Jhajharia D, Shrivastava SK, Sarkar D, Sarkar S (2009) Temporal characteristics of pan evaporation trends under the humid conditions of northeast India. Agric Meteorol 149:763-770

Liepert BG (2002) Observed reductions of surface solar radiation at sites in the United States and worldwide from 1961 to 1990. Geophys Res Lett 29:1421-1424

> Liepert BG, Feichter J, Lohmann U, Roeckner E (2004) Can aerosols spin down the water cycle in a warmer and moister world? Geophys Res Lett 31: L06207 doi:10.1029/ 2003GL019060

> Long SP, Ainsworth EA, Rogers A, Ort DR (2004) Rising atmospheric carbon dioxide: plants FACE the future. Annu Rev Plant Biol 55:591-628

Lugina KM, Groisman PYa, Vinnikov KYa, Koknaeva VV, Speranskaya NA (2007) Monthly surface air temperature time series area-averaged over the 30-degree latitudinal belts of the globe, 1881-2006. In: Trends: a compendium of data on global change. Carbon Dioxide Information Analysis Center, Oak Ridge National Laboratory, US Department of Energy, Oak Ridge, TN. Available at: http://cdiac.ornl.gov/trends/temp/lugina/lugina.html
Mahmood R (1997) Impacts of air temperature variations on the boro rice phenology in Bangladesh: implications for irrigation requirements. Agric Meteorol 84:233-247

MARM (Ministerio de Medio Ambiente y Medio Rural y Marino) (2010) Sistema de información climática para el regadío. MARM, Madrid. Available at: www.marm.es

> Martin P, Rosenberg NJ, McKenney MS (1989) Sensitivity of evapotranspiration in a wheat field, a forest, and a grassland to changes in climate and direct effects of carbon dioxide. Clim Change 14:117-151

> Martínez MD, Lana X, Burgueño A, Serra C (2007) Spatial and temporal daily rainfall regime in Catalonia (NE Spain) derived from four precipitation indices, years 1950-2000. Int J Climatol 27:123-138

Monteith JL, Unsworth MH (eds) (2008) Steady state heat balance: water surfaces, soil, and vegetation. I. In: Principles of environmental physics, 3rd edn. Elsevier, London, p 229-257

Palutikof J (2003) Analysis of Mediterranean climate data: measured and modelled. In: Bolle HJ (ed) Mediterranean climate. Springer, Berlin, p 125-132

Qian Y, Kaiser DP, Leung LR, Xu M (2006) More frequent cloud-free sky and less surface solar radiation in China from 1955 to 2000. Geophys Res Lett 33:L01812 doi:10. 1029/2005GL024586

Räisänen J, Hansson U, Ullerstig A, Doscher R and others (2004) European climate in the late twenty-first century: regional simulations with two driving global models and two forcing scenarios. Clim Dyn 22:13-31

- Ramos MC, Jones GV, Martínez-Casasnovas JA (2008) Structure and trends in climate parameters affecting winegrape production in northeast Spain. Clim Res 38:1-15

Ramos MC, Martínez-Casasnovas JA (2006) Trends in precipitation concentration and extremes in the Mediterranean Penedès-Anoia region, NE Spain. Clim Change 74: 457-474

Rana G, Katerji N (2000) Measurement and estimation of actual evapotranspiration in the field under Mediterranean climate: a review. Eur J Agron 13:125-153

Roderick ML, Farquhar GD (2002) The cause of decreased pan evaporation over the past 50 years. Science 298: 1410-1411

> Roderick ML, Farquhar GD (2004) Changes in Australian pan evaporation from 1970-2002. Int J Climatol 24: 1077-1090

Rodríguez-Puebla C, Nieto S (2009) Trends of precipitation over the Iberian Peninsula and the North Atlantic Oscillation under climate change conditions. Int J Climatol 30: $1807-1815$

Rosenberg NJ, McKenney MS, Martin P (1989) Evapotranspiration in a greenhouse-warmed world: a review and a simulation. Agric Meteorol 47:303-320

Ross RJ, Elliott WP (2001) Radiosonde-based Northern Hemisphere tropospheric water vapour trends. J Clim 14: 1602-1612

> Rowell DP, Jones RG (2006) Causes and uncertainty of future summer drying over Europe. Clim Dyn 27:281-299

Smith TM, Reynolds RW (2005) A global merged land-airsea surface temperature reconstruction based on historical observations (1880-1997). J Clim 18:2021-2036

> Soden BJ, Jackson DL, Ramaswamy V, Schwarzkopf MD, Huang X (2005) The radiative signatura of upper tropospheric moistening. Science 310:841-844

> Supit I, van Diepen CA, Boogaard HL, Ludwig F, Baruth B (2010) Trend analysis of water requirements, consumption and deficit of field crops in Europe. Agric For Meteorol 150:77-88 
Szilagyi J, Katul GG, Parlange MB (2001) Evapotranspiration intensifies over the conterminous United States. J Water Resour Plan Manage 127:354-362

Tebakari T, Yoshitani J, Suvanpimol C (2005) Time-space trend analysis in pan evaporation over Kingdom of Thailand. J Hydrol Eng 10:205-215

Trenberth KE, Jones PD, Ambenje P, Bojariu R and others (2007) Observations: surface and atmospheric climate change. In: Solomon S, Qin D, Manning M, Chen Z and

Submitted: December 21, 2009; Accepted: August 6, 2010 others (eds) Climate change 2007: the physical science basis. Contribution of Working Group I to the Fourth Assessment Report of the Intergovernmental Panel on Climate Change. Cambridge University Press, Cambridge, p 235-336

> Xu C, Gong L, Jiang T, Chen D, Singh VP (2006) Analysis of spatial distribution and temporal trend of reference evapotranspiration and pan evaporation in Changjiang (Yangtze River) catchment. J Hydrol 327:81-93

Proofs received from author(s): September 29, 2010 